The silicone products so obtained are characterized by good resistance both to water and to extremes of temperature. 'These are extremely useful properties, and result in silicones being used for such varied purposes as paints for metal surfaces at high temperatures, water-repellent treatment for masonry, concrete, etc., heat-resistant electrical insulation, silicone finishes to fabrics to achieve water repellency and stain resistance, etc. The quality of the products is tested in a technical service laboratory, and the development of new products is also carried out there.

The knowledge and experience of the Dow Corning Corporation in the field of silicone science and technology has been freely available and has been drawn on liberally in the setting up of this plant at Barry.

\section{BIOLOGICAL EVALUATION OF WATER AND EFFLUENTS}

$\mathrm{O}$ November 3 the Biological Methods Group of the Society for Analytical Chemistry held a symposium in London on "The Biological Evaluation of Water and Effluents". The large attendance and the spirited discussion of the papers gave a good indication of the large number of chemists and biologists now interested - either as consultants or as servants of public authorities or industrial firms-in the assessment and control of pollution.

Dr. B. A. Southgate (Water Pollution Research Laboratory, Stevenage), in introducing the subject, said that, in trying to evaluate the purity either of a surface water or a polluting discharge, chemical and biological methods are usually used in conjunction. Waters to be used as a source of domestic -or sometimes industrial - supply are usually examined bacteriologically; with some surface waters the algal flora is examined frequently, and measures are taken to prevent its interfering with filtration and other methods of treatment of the water. There is a great lack of quantitative information on the distribution of different species of fish in rivers, particularly in rivers polluted by sewage and industrial effluents. Recent work has shown that large numbers of coarse fish enter a channel carrying an undiluted sewage effluent, in which conditions only rarely become lethal; when lethal conditions do occur, it is due principally to depletion of oxygen in solution.

In regulating the discharge of effluents containing oxidizable matter to a stream, a method is urgently required whereby the effect of a given discharge on the oxygen tension in the stream can be predicted. Usually effluents are examined by the test for biochemical oxygen demand or, better, by measuring uptake of oxygen in a respirometer (of which a new modification of an instrument of the Warburg type was described), but it is by no means certain that the rate of oxidation-particularly of ammoniameasured in this way is the same as that which occurs in a stream. In the direct measurement of rate of oxidation in a river, it is necessary to be able to determine the rate of solution of oxygen from the air-known to vary widely with turbulence, surface agitation, and other factors. Dr. Southgate described an attempt to do this by following changes in the oxygen content of air trapped in a light plastic container, open at the bottom, and floating on the surface of the water. Rapid fluctuations may occur in the oxygen tension in polluted streams, and methods of recording the level of oxygenation, con- tinuously or at short intervals, are required. A recently developed apparatus was described in which samples are taken at intervals of ten minutes, the oxygen content being determined automatically, essentially by the method of Winkler; the values obtained are recorded on a chart.

The determination of the toxicity of effluents to fish was then dealt with by Mr. D. W. M. Herbert (Water Pollution Research Laboratory, Stevenage) ; the object of this work, he said, is to predict, from tests in the laboratory, what effect a given effluent would have on fish when discharged to a river. Laboratory tests under controlled conditions can usually be made only during a period of a few days, though some have been continued for as long as three months; from tests of this kind, one has to try to predict what the effect of a small concentration of a poison, present continuously in a river, would be on a fishery. It is very probable that the toxicity of a river water, containing a fixed concentration of a poison, would in any event fluctuate widely, since the toxicity of most direct poisons which have been examined increases markedly as the oxygen tension of the water containing them is reduced below the air-saturation value. Fluctuations in temperature and $p \mathrm{H}$ value may also be important ; the toxicity of solutions of ammonia, for example, increases rapidly as the $p \mathrm{H}$ rises and ionization is suppressed.

Dr. J. E. Forrest (Queen Mary College, London) described the effects of polluting discharges on the flora and invertebrate fauna of streams, dividing effluents for this purpose into those containing direct poisons ; those, such as sewage effluents, not directly poisonous but containing organic matter; and those which affect a river mainly by raising its temperature. Below a source of serious organic pollution there is a well-marked sequence of changes in the invertebrate fauna and, it was suggested, a study of the fauna in a river might give more reliable information about the state of pollution of the water than would be given by random chemical tests. The relative importance of the level of oxygenation of the water and of the nature of the bottom in influencing the distribution of invertebrates is not yet clear. Normally, of course, if mud and sludge are to be deposited in a river, this will happen in slowflowing and relatively deep reaches where the oxygen tension of the water is likely to be low, as a result of uptake of oxygen at the mud-water interface, and of the relatively small rate of re-aeration of the water from the air under stagnant conditions. The importance of Cladophora (blanket weed) in modifying the character of a stream was stressed; this alga may grow very vigorously in rivers polluted by nitrogenous organic matter.

In a paper on the determination of the safety of water, Dr. E. Windle Taylor (Metropolitan Water Board, London) described the development which has taken place, from about 1880 onwards, of bacteriological methods of examination. Recently, for research purposes, the probable error of bacterial counts, using liquid media, has been considerably reduced by using only two-fold dilutions and examining seven series, each of ten tubes, in each determination; the modern view, however, is that in routine estimations to safeguard the purity of a domestic water supply it is better to increase the number of samples examined rather than to increase the number of tests carried out on each sample. He emphasized that a public water undertaking aims at distributing a safe, but not necessarily 
a sterile, water ; sterilization may be necessary if the water is used in a hospital, and for process water in food industries further treatment may be desirable to improve the keeping qualities of the product. Among the most promising recent developments in methods of examining water are membrane filtration, and the use of synthetic media containing only pure inorganic substances. Dr. Windle Taylor urgedand this was strongly supported in discussion of his paper-that standard bacteriological methods should be used in examining water supplies. Several members also referred to the urgent need for a second edition of "Methods of Chemical Analysis as applied to Sewage and Sewage Effluents", the first edition of which was published by the Ministry of Health as long ago as 1929.

The discussion-a very brisk one-which followed the papers covered a wide range. Opinion seemed to be general that there is a need for a standard method of determining the toxicity of industrial effluents to fish ; an attempt is in fact now being made to develop such a method, and the Ministry of Agriculture and Fisheries has announced that it proposes to set up a laboratory in London in which samples submitted will be tested. Several speakers referred to the inadequacy of the widely used test for biochemical oxygen demand of effluents, and it is clear that much further work is required to determine rates of oxidation of pollutants, both under laboratory conditions and in different types of rivers. Only when this information is available will it be possible to predict with confidence the effect of an effluent on the level of oxygenation of a river-a very important matter to a river board proposing to frame by-laws regulating the quality of effluents in its district.

\section{RESEARCH ADMINISTRATION CONFERENCE}

$\mathrm{T}$

HE eighth annual conference on "The Administration of Research" brought together nearly three hundred leaders of industrial, university and government research laboratories at New York University during September 8-10, coinciding with the opening of the centennial celebration of the College of Engineering of that University. The Conference is arranged each year by an informally organized group, mainly administrators of research and development in the physical sciences. Attendance is by invitation and proceedings are published by the host university. The programme for 1954 was designed for discussing specific incidents pertaining to management of the 4,000 million dollar research and development business throughout the United States.

At each half-day symposium a series of four or five brief presentations was followed by lively discussion. The first symposium, "Appraising and Rewarding the Researcher's Output", was opened by Dr. Exic A. Walker, dean of engineering at Pennsylvania State College, where the Conference was founded in 1947. Observing that "we have passed through the stage of random creativeness and entered an age of deliberate creativity", Dr. Walker said it is up to the research man to sketch the course the engineer will follow toward the prophesied increase of 100,000-150,000 million dollars in the gross product of the United States by 1960. Although no objective measure of an individual scientist's productivity has yet been found, the fact that empirical evaluations are becoming more prevalent and systematic was brought out by each speaker.

Mr. Edwin A. Speakman, general manager, Guided Missiles Division, Fairchild Engine and Airplane Corporation, described the semi-annual rating plan of his company. He noted that supervisors and administrators must often evaluate and reward a researcher's potential far in advance, as it may take several years for his efforts to materialize. Dr. Clyde E. Williams, director of the Battelle Memorial Institute, emphasized that scientific integrity, selflessness and ability to work in a team are considered most important for promotion. The National Bureau of Standards, according to its director, Dr. A. V. Astin, favours appraisal and promotion of staff members through the collective judgment of committees at various levels. Although it is possible to promote a scientist to the highest grade without assigning him executive responsibility, such assignments are difficult to avoid, and Dr. Astin suggested that this situation warrants further study.

The Conference speaker from outside the United States was Dr. John J. Green, of the Defence Research Board of Canada, who is science advisor to the Royal Canadian Air Force. He summarized, with individual examples, awards which are available for merit in research; these include sabbatical years, cash awards, royalties from inventions, the Queen's honours lists, and the annual gold medal of the Professional Institute of the Civil Service of Canada.

After a luncheon, addressed by Henry T. Heald, chancellor of New York University, the second symposium dealt with a number of general aspects of "Management in the Research Laboratory". The chairman, Dr. James B. Austin, vice-president of the Research Division, United States Steel, gave some pointers on the "Control of Service Groups". $\mathrm{He}$ emphasized the concept of service to the research staff, pointing out that machine-shop backlog must be small enough to accommodate rush-work for scientists. Informal contacts by the scientist with the service technician are encouraged and priority determinations in shops work, for example, are made through weekly conferences. In exploring "The Use of Work Simplification in a Research Laboratory", Mr. Allan H. Mogensen, management consultant, gave examples of how other organizations have been helped by such a programme. He urged that all workers be taught to keep asking 'why', and recommended direct communication, rather than suggestion boxes, as the channel for ideas.

The delicate problem of "Inter-Departmental Relations of Research to Production and Sales" was treated by Mr. Kenneth H. Klipstein, general manager of the Research Division, American Cyanamid Co. Not only individuals but also whole sections of an organization must practise team-work in to-day's industry and government. To have the research director as a part of top management and to use co-ordinating committees for active planning and review are approaches $\mathrm{Mr}$. Klipstein has found most effective. Similar experience was described by Dr. Blaine B. Wescott, executive vice-president, Gulf Research and Development Co. Having research consolidated in one department rather than dispersed among operating departments, he agrees, has more advantages than disadvantages. Qualifications of an engineering manager were discussed by $\mathrm{Mr}$. Howard L. Richardson, vice-president of engineering oper- 